\title{
Piezoelectric transducer design for electric power generation
}

\section{Diseño de transductor piezoeléctrico para generación de potencia eléctrica}

\author{
Edwin F. Forero-García ${ }^{1 a}$, Óscar M. Gélvez-Lizarazo ${ }^{\text {bb }}$, Carlos A. Torres-Pinzón ${ }^{1 \mathrm{c}}$ \\ ${ }^{1}$ Grupo de Investigación Modelado-Electrónica-Monitoreo, Facultad de Ingeniería Electrónica, Universidad Santo Tomás, \\ Colombia. Orcid: ${ }^{\mathrm{a}} 0000-0002-3818-7793,{ }^{\mathrm{b}} 0000-0001-6858-5293,{ }^{\mathrm{c}} 0000-0003-0367-8143$. \\ Email: a edwinforero@ usantotomas.edu.co, b oscargelvez@ usantotomas.edu.co, ${ }^{\mathrm{c}}$ carlostorresp@ usantotomas.edu.co
}

Received: 31 January 2018. Accepted: 15 April 2018. Final version: 22 June 2018.

\begin{abstract}
Working on alternatives for harnessing and transforming different forms of energy in a clean and efficient way, like piezoelectric phenomena, allows considering collecting energy that is commonly wasted. For example, the piezoelectricity facilitates the harvesting of energy derived from the weight discharged by humans when walking on a surface conditioned with piezoelectric transducers. However, the technology in this field has always advanced in the opposite direction, i.e. the conversion of electric energy into vibrations for different applications. In this work, the design of the material structure for a piezoelectric device of low resonance frequency for the capture of electricity is considered. The purpose of this device is the efficient transformation of mechanical energy into electrical energy; for this reason, the design of its configuration counts with a resonance frequency of less than $100 \mathrm{kHz}$. For this, the characteristics of the area dimensions and their relationship to the thickness according to the deposited material and the performance according to the projected impact were established. Moreover, the selection of the substrate was established according to the fracture requirements, acknowledging the mechanical loading loads of the transducer.
\end{abstract}

Keywords: energy; frequency; piezoelectric; transducer; transformation.

\section{Resumen}

Al trabajar en alternativas para aprovechar y transformar diferentes formas de energía de una manera limpia y eficiente, se considera el fenómeno piezoeléctrico, el cual permite la recolección de energía que comúnmente se desperdicia. Por ejemplo, la piezoelectricidad facilita la recolección de energía derivada del peso descargado por los humanos cuando se camina sobre una superficie acondicionada con transductores piezoeléctricos. Sin embargo, la tecnología en este campo siempre ha avanzado en la dirección opuesta, es decir, se ha trabajado en la conversión de energía eléctrica en vibraciones para diferentes aplicaciones, pero no lo contrario. En este trabajo, se considera el diseño de la estructura del material para un dispositivo piezoeléctrico de baja frecuencia de resonancia para la captura de electricidad. El propósito de este dispositivo es la transformación eficiente de la energía mecánica en energía eléctrica, por esta razón el diseño de su configuración considera una frecuencia de resonancia de menos de $100 \mathrm{kHz}$. Para esto, se establecieron las características de las dimensiones del área y su relación con el espesor de acuerdo con el material depositado y el rendimiento de acuerdo con el impacto proyectado. Además, la selección del sustrato se consideró de acuerdo con los requisitos de fractura, teniendo en cuenta la magnitud de carga mecánica al transductor.

Palabras clave: piezoeléctrico; energía; frecuencia; transformación, transductor.

ISSN Printed: 1657 - 4583, ISSN Online: 2145 - 8456, CC BY-ND 4.0 (c) (i) $\ominus$

How to cite: E. F. Forero-García, O. M. Gelvez-Lizarazo, C. A. Torres-Pinzón, "Piezoelectric transducer design for electric power generation," Rev. UIS Ing., vol. 18, no. 1, pp. 119-126, 2019. doi: 10.18273/revuin.v18n1-2019010 


\section{Introduction}

The need to find transformation alternatives capable of taking advantage of daily human activities directs the attention to the piezoelectric phenomenon, which is the propriety of some materials to transform mechanical movements into electricity. For example, it can be exploited while walking. For this, you can arrange the piezoelectric transducer in shoes or directly on the floor. The contribution of this work allows gaining experience in the own design of devices and materials that perform the energy conversion.

Nowadays, technology has advanced in the development of different transducers, where its manufacture and performance are subject to the characteristics of the materials used in the process. Different piezoelectric elements manufactured are used as transforming elements of mechanical energy into electrical energy; however, the designs found have characteristics for specific applications and are commercially expensive. In this paper, we present a study of the different possibilities that have been taking care of the piezoelectric characteristics such as voltage, power and frequency for electricity generation.

Moreover, this paper discusses the effect of geometric parameters in obtaining different characteristics for an efficient transformation of mechanical energy into electrical energy so that the design of the piezoelectric configuration considers a resonance frequency of less than $100 \mathrm{kHz}$

\section{Physical principle}

A piezoelectric crystal can be defined as a crystal in which electricity or electric polarity is produced by pressure or is electrified to compression. Reciprocally, it is defined as a material with an electric field.

When a piezoelectric material is subjected to a compression or a positive pressure, this acquires polarity. If the pressure is replaced by a stretching (i.e. a change of sign of pressure), the sign of the electric polarity is reversed, too. Then, the piezoelectric effect is the electrical response that a material has against a positive or negative value of mechanical pressure applied between its ends. A crystal structure with piezoelectric properties has set some parameters to quantify its response. An important parameter is the "one-wayness" or region where the sign of the pressure exerted is determined. On the other hand, the same one- wayness determines the sign of deformation when an electric field is applied to the crystal. This change of sign results in the voltage with the field sample that distinguishes the electrostriction piezoelectricity.

A pressure exerted on two piezoelectric crystals causes a deformation of their molecular state causing a collision between atoms. When the crystal is compressed, the ionized (charged) atoms present in the structure of each cell of formation of the crystal move, causing the electric polarization of it. Due to facts that the regularity of the crystal structure and the deformation effects of the cell develop in all the cells of the body of the crystal, these charges add up, and an accumulation of the electric charge occurs, producing a difference of electric potential between certain faces of the crystal in which the pressure is exerted.

Of the 32 crystals classes, there are 20 that possess one wayness [1]. In the others, there is no way to decide the direction of compression or polarity, as these materials are not significantly polarized. The effect of applying a voltage to deform a crystal is not always reciprocal; it depends on the structure of the crystal because the deformation can be pure or at different angles with respect to the electric field.

A piezoelectric crystal is one that deforms in an electric field, depending on the relationship between the applied voltage and the resulting polarization. Stress can be a compression or an extension, but it can also be a shear stress, which is closely related to compression. There is a kind of crystal in which a random stress produces a polarization, proportional to the direction and amount of it indeed, that varies with stress. This material is called triclinic asymmetric and corresponds to the material of lower symmetry at present. There are no materials with piezoelectric properties in a single direction, but there are several kinds of materials where polarization is limited in one plane [1]. In contrast, an applied field must have at least one component in the order of the plane where piezoelectric deformation occurs.

\section{Discussion}

The most relevant parameters in the study of piezoelectric materials are the piezoelectric coupling factor $\mathrm{K}(\mathrm{K} 33, \mathrm{~K} 31, \mathrm{KP}$ and $\mathrm{Kt})$, mechanical quality factor $(\mathrm{Qm})$, frequency constant $(\mathrm{Nl})$, piezoelectric coefficients of voltage (g33 and g31) and displacement per charge (d33 and d31) [1]. Currently, different materials are found with piezoelectric characteristics. Nonetheless, the application leads to choosing materials with specific propertie; for instance, for electric power generation, the ceramic materials of excellent properties are PZT (5 A, 5H), PMN-PT, ZnO used as bulk material $[2,3]$. 
Table 1. Piezoelectric Properties [2].

\begin{tabular}{|c|c|c|c|c|c|c|}
\hline Property & Units & Symbol & PZT 5 A & PZT 5H & PMN-PT & $\mathrm{ZnO}$ \\
\hline Density & $\mathrm{g} / \mathrm{cm}^{3}$ & $\mathrm{P}$ & 7,8 & 7,8 & 8,0 & 5,6 \\
\hline $\begin{array}{l}\text { Dielectric Constant } \\
(<100 \mathrm{KHz})\end{array}$ & - & $\mathrm{K}^{\mathrm{T}}{ }_{3}$ & 1900 & 3800 & 5400 & 87,0 \\
\hline $\begin{array}{l}\text { Mechanical Quality } \\
\text { Factor }\end{array}$ & - & $\mathrm{Q}_{\mathrm{m}}$ & 80 & 30 & 80 & 120 \\
\hline \multirow{4}{*}{ Coupling Coefficients } & \multirow{4}{*}{ - } & $\mathrm{k}_{\mathrm{p}}$ & 0,65 & 0,75 & & 0,33 \\
\hline & & $\mathrm{k}_{33}$ & 0,72 & 0,75 & 0,91 & 0,42 \\
\hline & & $\mathrm{k}_{31}$ & 0,36 & 0,43 & 0,44 & - \\
\hline & & $\mathrm{k}_{\mathrm{t}}$ & 0,48 & 0,55 & 0,60 & 0,46 \\
\hline \multirow{2}{*}{$\begin{array}{l}\text { Piezoelectric Charge } \\
\text { (Displacement) } \\
\text { Coefficient }\end{array}$} & \multirow{2}{*}{$\begin{array}{l}\mathrm{C} / \mathrm{N} \times 10^{-12} \\
\text { or } \mathrm{m} / \mathrm{V} \times 10^{-} \\
{ }_{12}\end{array}$} & $\mathrm{~d}_{31}$ & -190 & -320 & -699 & $-5,4$ \\
\hline & & $\mathrm{d}_{33}$ & 390 & 650 & 1540 & 11,7 \\
\hline \multirow{2}{*}{$\begin{array}{c}\text { Piezoelectric Voltage } \\
\text { Coefficient }\end{array}$} & \multirow{2}{*}{$\mathrm{V} \cdot \mathrm{m} / \mathrm{N} \times 10^{-3}$} & $\mathrm{~g}_{33}$ & 24,0 & 19,0 & 32,2 & 15.2 \\
\hline & & $\mathrm{g}_{31}$ & $-11,3$ & $-9,5$ & $-14,6$ & -7.0 \\
\hline \multirow{2}{*}{ Elastic Modulus } & \multirow{2}{*}{$\mathrm{N} / \mathrm{m}^{2} \times 10^{10}$} & $\mathrm{Y}^{\mathrm{E}_{11}}$ & 6,7 & 6,3 & 1,9 & 20,97 \\
\hline & & $\mathrm{Y}_{33}$ & 5,3 & 5,0 & 1,7 & 21,09 \\
\hline Poisson's Ratio & - & $\mathrm{Y}$ & 0,31 & 0,31 & 0,37 & 0,31 \\
\hline Acoustic velocity & $\mathrm{m} / \mathrm{s}$ & Vs & 4350 & 4560 & 1540 & 2724 \\
\hline
\end{tabular}

\subsection{Frequency of resonance according to the geometry of the piezoelectric material}

The resonance frequency is defined by the parameters of the piezoelectric material as well as the determination of its geometric structure $[1,4]$. According to the aim of this work, it is important to determine and guide the design at low frequencies because the mechanical impacts considered are also of low frequencies.

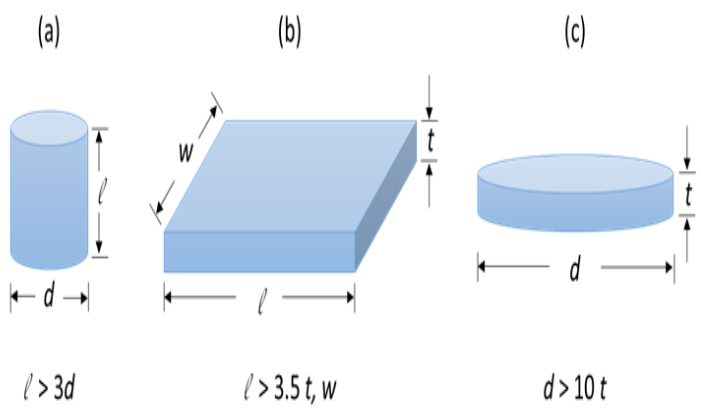

Figure 1. Design features of different geometries of piezoelectric material. (a) Pole rod, and (b) thin flat plate and (c) thin flat disc.

The resonance frequency for different geometries of piezoelectric material is established by Equation 1 and Equation 2.

$$
\begin{aligned}
& N_{l}=l * f_{r}=\frac{1}{2} \sqrt{\frac{Y}{\rho}} \\
& f_{r}=\frac{V s}{2 * t}
\end{aligned}
$$

Where 1 is the length of the piezoelectric ceramic thin plate, $\mathrm{t}$ is the thickness of thin flat disc, $V s$ refers to the sound velocity, $f_{r}$ is the resonance frequency in the length direction, $Y$ is Young's modulus, and $\rho$ is the density $[1,2]$.

Table 2. Resonance frequency

\begin{tabular}{|c|c|c|c|c|}
\cline { 2 - 5 } \multicolumn{1}{c|}{ Geometry } & $\begin{array}{c}\text { Pole } \\
\text { rod }\end{array}$ & $\begin{array}{c}\text { Thin flat } \\
\text { plate }\end{array}$ & $\begin{array}{c}\text { Thin } \\
\text { flat } \\
\text { disc }\end{array}$ \\
\cline { 2 - 5 } \multicolumn{1}{c|}{} & Dimensions & $\begin{array}{c}l(30), \\
d(10) \\
m m\end{array}$ & $\begin{array}{c}t(10), \\
l=\mathrm{w} \\
(35) \mathrm{mm}\end{array}$ & $\begin{array}{c}t(10), \\
d(100) \\
m m\end{array}$ \\
\hline \multirow{3}{*}{$f_{r}$} & PZT 5 A & 72,5 & 37,23 & 217,5 \\
\cline { 2 - 5 }$(\mathrm{kHz})$ & PZT 5H & 76,0 & 36,17 & 228 \\
\cline { 2 - 5 } & PMN-PT & 25,7 & 225,87 & 77 \\
\cline { 2 - 5 } & ZnO & 45,4 & 87,67 & 136,2 \\
\hline
\end{tabular}




\subsection{Capacitance according to the geometry of the piezoelectric material}

The capacitance for different geometries of piezoelectric material is demonstrated by Equations 3 and 4 [5].

$$
\begin{gathered}
C_{p}=\frac{l * W * k_{3}^{T}}{4.45 * t} \\
C_{d}=\frac{d^{2} * k_{3}^{T}}{5.67 * t}
\end{gathered}
$$

Where $\mathrm{Cp}$ and $\mathrm{Cd}$ are the thin flat plate and thin flat disc capacitance respectively, $1, \mathrm{~W}, \mathrm{~d}$ (in) and $\mathrm{t}(10-3 \mathrm{in})$ [3].

Table 3. Capacitance

\begin{tabular}{|c|c|c|c|c|}
\hline \multirow{2}{*}{ Geometry } & $\begin{array}{c}\text { Pole } \\
\text { rod }\end{array}$ & $\begin{array}{c}\text { Thin } \\
\text { flat } \\
\text { plate }\end{array}$ & $\begin{array}{c}\text { Thin flat } \\
\text { disc }\end{array}$ \\
\hline \multirow{2}{*}{ Dimensions } & $\begin{array}{c}l(30), \\
d(10) \\
m m\end{array}$ & $\begin{array}{c}t(10), \\
l=\mathrm{w} \\
(35) \mathrm{mm}\end{array}$ & $\begin{array}{c}t(10), d \\
(100) \mathrm{mm}\end{array}$ \\
\hline \multirow{3}{*}{$\mathrm{C}$} & PZT 5 A & 43,98 & 2059,19 & 13192,79 \\
\cline { 2 - 5 }$(\mathrm{nF})$ & PZT 5H & 87,95 & 4118,38 & 26385,59 \\
\cline { 2 - 5 } & PMN-PT & 124,98 & 5852,43 & 37495,31 \\
\cline { 2 - 5 } & $\mathbf{Z n O}$ & 2,01 & 94,29 & 604,09 \\
\hline
\end{tabular}

3.3. Voltage generated by applied load according to the geometry of the piezoelectric material

The piezoelectric constant dij is the ratio of short circuit charge per unit area flowing between connected electrodes perpendicular to the $\mathrm{j}$ direction to the stress applied in the i direction. As shown in Figure 2, once a force $\mathrm{F}$ is applied to the transducer, in the direction 3, it generates the stress [6].

One of the considerations of the simulation is the ability to withstand mechanical stress according to the geometric structure as seen in Figures 3, 4, and 5, for each of the geometries used. That is why it is considered a detailed analysis of the power generation capacity, taking into consideration the applied force.
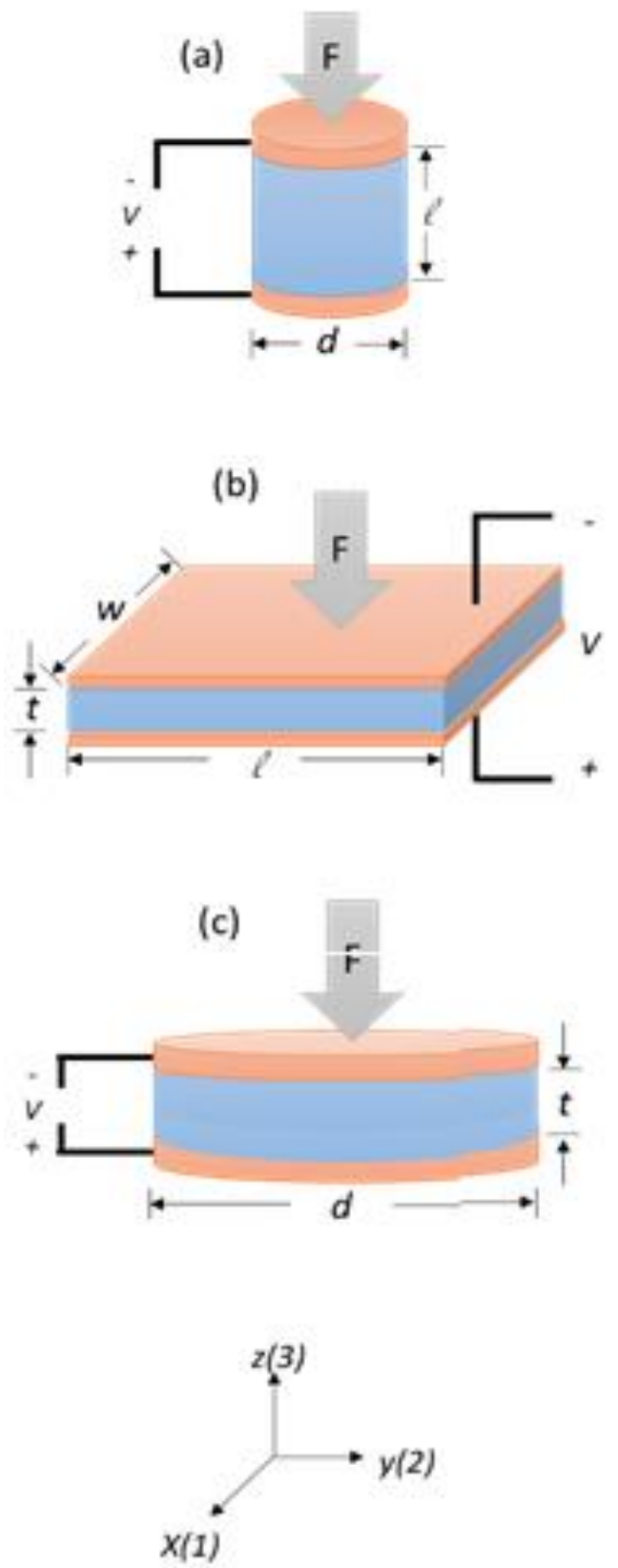

Figure 2. Voltage generated by applied load according to the geometries of piezoelectric material. (a) Pole rod, (b) thin flat plate and (c) thin flat disc. 
Superficie: Tensión von Mises $\left(\mathrm{N} / \mathrm{m}^{2}\right)$

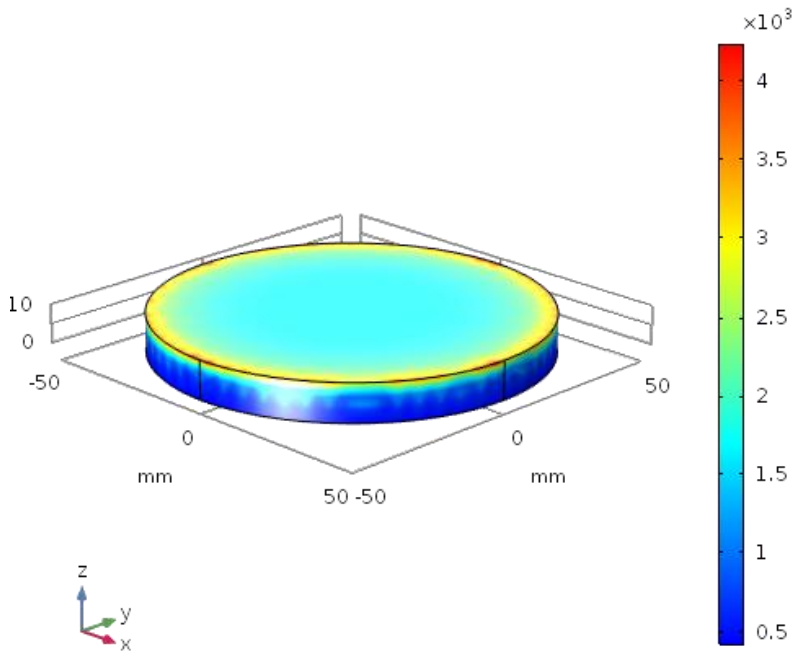

Figure 3. Applied load according to the geometries of piezoelectric material - thin flat disc.

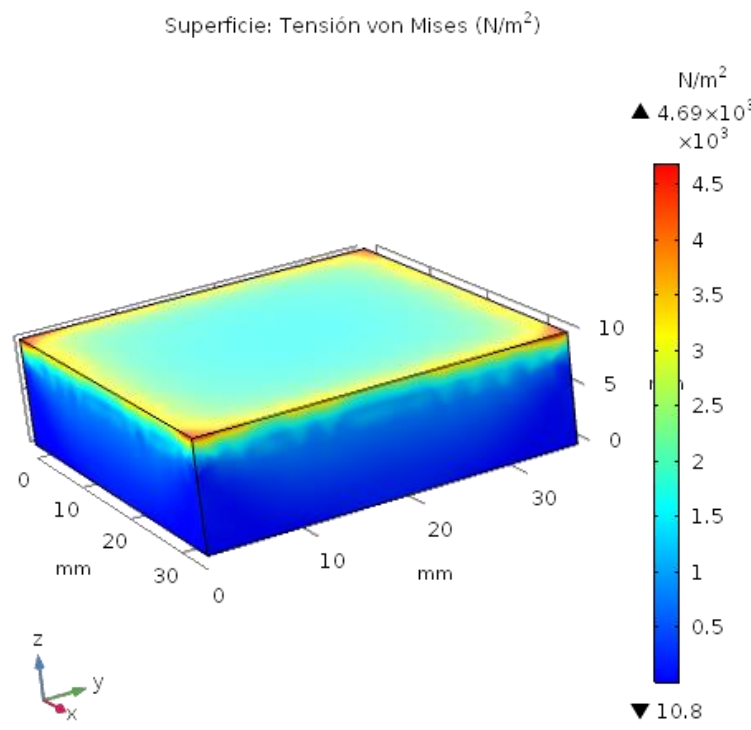

Figure 4. Applied load according to the geometries of piezoelectric material - flat plate.

The voltage generated by applied load for different geometries of piezoelectric material is determined by Equations 3 and 4.

$$
q=d_{33} F
$$

$$
V_{p}=\frac{g_{31} F}{C_{p}}
$$

From the distribution of the force applied to the piezoelectric material as a function of the geometries studied, the electric voltage generated by the action of an external force is obtained, resulting in Figures 6,7 and 8.

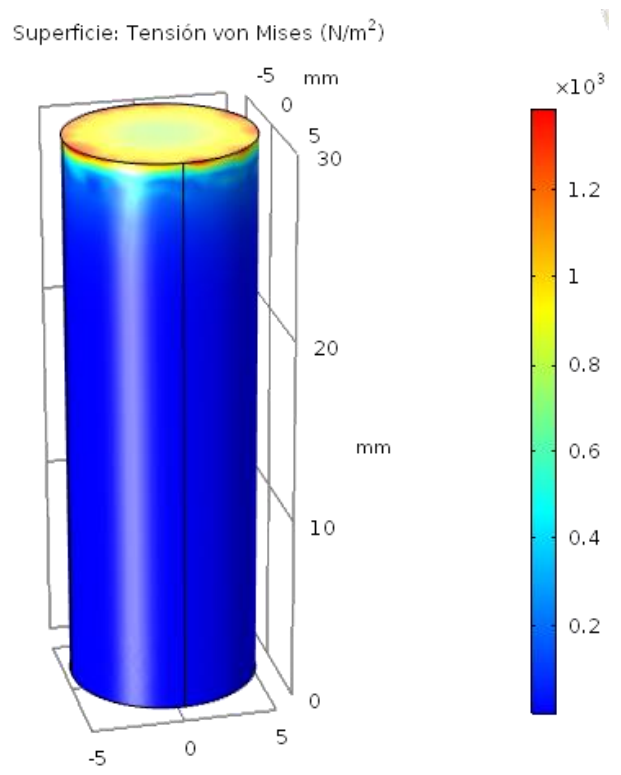

Figure 5. Applied load according to the geometries of piezoelectric material - pole rod.

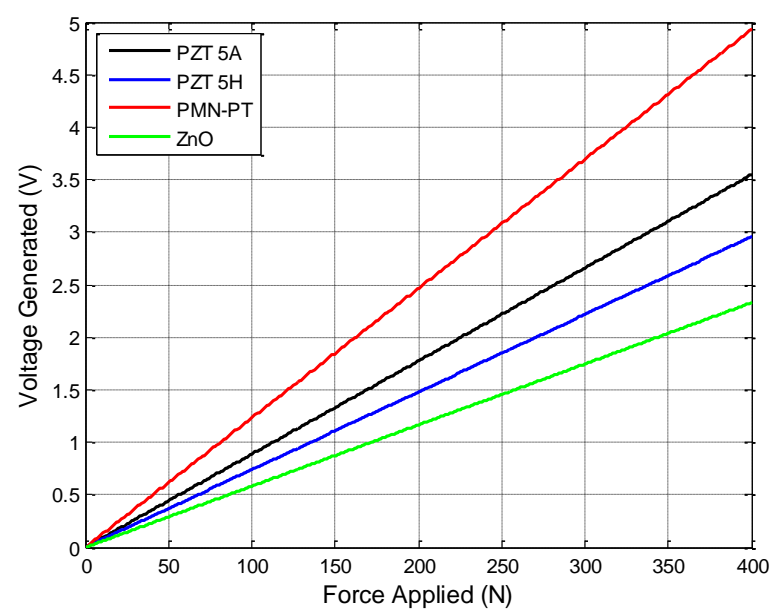

Figure 6 . Voltage generated by applied load according to the geometries of piezoelectric material - Pole rod. 


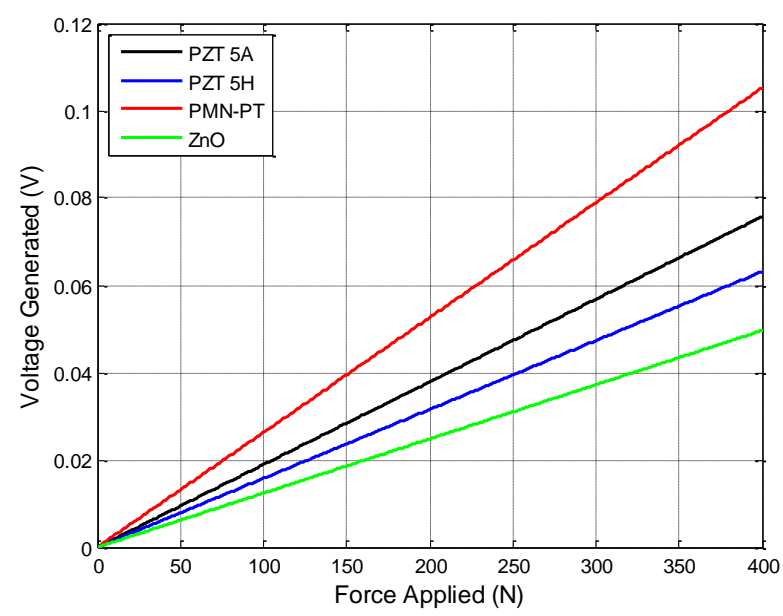

Figure 7. Voltage generated by applied load according to the geometries of piezoelectric material - thin flat plate.

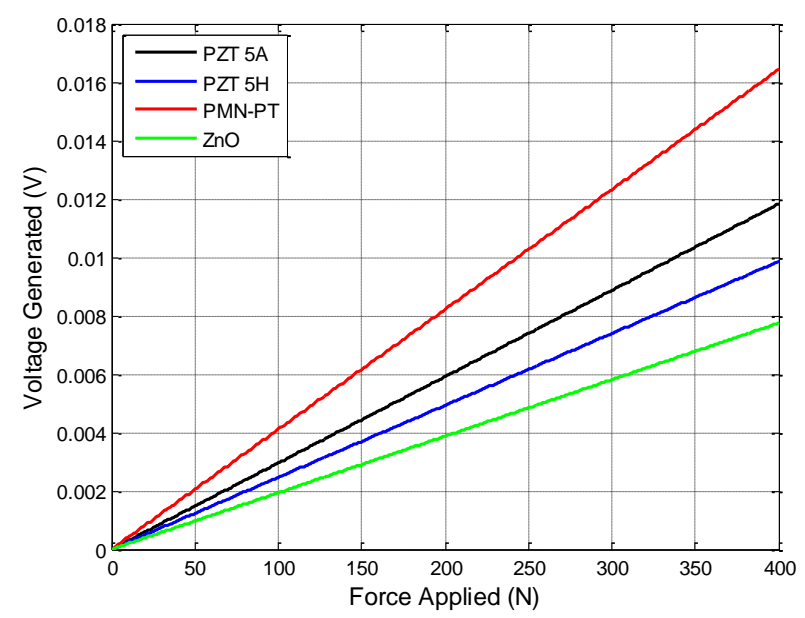

Figure 8 . Voltage generated by applied load according to the geometries of piezoelectric material - thin flat disc.

From Figures 3, 4 and 5, it is possible to define the cylindrical geometric shape as a structure for the design of the transducer, considering that the possible generation of tension by applied force is greater in relation to its counterparts of thin planes. In addition, it is important to note that the lowest frequencies obtained come from this structure.

\section{Conclusions}

This paper showed the justification for the design of a piezoelectric device with the purpose of obtaining electrical energy from mechanical impacts. For this, the foundation of the piezoelectric phenomenon and the parameters to consider for the design were presented.
Moreover, different geometries were analyzed by simulation under the same conditions of effort to select a final design.

As a result of this work, the effect of geometric parameters in obtaining different characteristics for an efficient transformation of mechanical energy into electrical energy is presented. It was found that the cylindrical geometry of the piezoelectric material favors the generation of greater electrical potential between the electrodes of the device, considering an increase of $99.53 \%$ with regard to the thin-plane geometry.

For the future works, the material to be used is considered PMN-PT, given that its piezoelectric characteristics next to the design and geometry defined for the manufacture of the device determined by this study.

\section{References}

[1] W. G. Nelson, Piezoelectric Materials: Structure, Properties and Applications. New York: Nova Science Publishers Inc, 2010.

[2] PPA, "PPA Products Datasheet - User Manual," 2017. [Online]. Available: https://info.mide.com/piezoproducts/download-piezo-products-datasheets.

[Accessed: Feb 02, 2017]

[3] M. Takeuchi, H. Yamada, Y. Yoshino, T. Makino and S. Arai, "Effective electromechanical coupling coefficient (kt2) for fundamental mode of thickness extensional mode thin film bulk acoustic wave resonator fabricated by $\mathrm{ZnO}$ thin film," Vacuum, vol. 66, no. 3-4, pp. 463-466, 2002. doi: 10.1016/S0042-207X(02)001161

[4] Y. Q. Fu et al., "Advances in piezoelectric thin films for acoustic biosensors, acoustofluidics and lab-on-chip applications," Prog. Mater. Sci., vol. 89, pp. 31-91, 2017. doi: 10.1016/j.pmatsci.2017.04.006

[5] CTS Corporation (NYSE: CTS), "Piezoelectric Sense Products," [Online]. Available: http://www.ctscorp.com/products/piezoelectricproducts/. [Accessed: April 21, 2017].

[6] P. Dineva, D. Gross, R. Müller, y T. Rangelov, Dynamic Fracture of Piezoelectric Materials, vol. 212. Cham: Springer International Publishing, 2014. doi: 10.1007/978-3-319-03961-9

[7] P. P. Vergara-Barrios, J. M. Rey-López, G. A. OsmaPinto and G. Ordóñez-Plata, "Evaluación del Potencial solar y eólico del campus central de la Universidad 
Industrial de Santander y la ciudad de Bucaramanga, Colombia," Rev. UIS Ing., vol. 13, no. 2, pp. 49-57, 2014.

[8] F. A. Pavas- Martinez, O. A. Gonzalez-Vivas and Y. S. Sanchez-Rosas, "Cuantificación del ahorro de energía eléctrica en clientes residenciales mediante acciones de gestión de demanda," Rev. UIS Ing., vol. 12, no. 2, pp. 217-225, 2017. doi: 10.18273/revuin.v16n2-2017020

[9] S. Han and C. Huh, "Analysis of a Piezoelectric Generator Under an Elastic Wave," in IEEE Transactions on Plasma Science, vol. 45, no. 11, pp. 3001-3006, 2017. doi: 10.1109/TPS.2017.2752205

[10] Y. Wang, L. Wang, T. Cheng, F. Qin and Z. Song, "Design and simulation analysis of a novel pneumaticpiezoelectric generator," 2015 International Conference on Fluid Power and Mechatronics (FPM), Harbin, 2015, pp. 413-416. doi: 10.1109/FPM.2015.7337151

[11] D. Grzybek, "Piezoelectric generator for the power supply of the monitoring system," Proceedings of the 2014 15th International Carpathian Control Conference (ICCC), Velke Karlovice, 2014, pp. 135-138. doi: 10.1109/CarpathianCC.2014.6843584

[12] S. Akkaya Oy and A. E. Özdemir, "Usage of piezoelectric material and generating electricity," 2016 IEEE International Conference on Renewable Energy Research and Applications (ICRERA), Birmingham, 2016, pp. 63-66. doi: 10.1109/ICRERA.2016.7884363

[13] D. Tibaduiza, M. Anaya, E. Forero, R. Castro, y F. Pozo, "A Sensor Fault Detection Methodology applied to Piezoelectric Active Systems in Structural Health Monitoring Applications", IOP Conf. Ser. Mater. Sci. Eng., vol. 138, no. 1, p. 12016, 2016.

[14] F. Lu, H. P. Lee and S. P. Lim, "Modeling and analysis of micro piezoelectric power generators for micro-electromechanical-systems applications," Smart Mater. Struct., vol. 13, no. 1, pp. 57-63, 2004.

[15] N. Ismall and R. A. Ghani, "Advance devices using piezoelectric harvesting energy," 2013 IEEE Student Conference on Research and Developement, Putrajaya, 2013, pp. 450-453. doi: 10.1109/SCOReD.2013.7002629

[16] J. Kang, J. Noh, Y. Oh, L. Hwang and J. Yoo, "Piezoelectric energy harvesting using lead-free (Na0.5K0.5)0.97(Nb0.96Sb0.04)O3 ceramics," 2010 IEEE International Symposium on the Applications of Ferroelectrics (ISAF), Edinburgh, 2010, pp. 1-3. doi: 10.1109/ISAF.2010.5712221
[17] M. Anwar, L. Hakim and N. Nadzri, "Prototype of a low power energy harvesting using piezoelectric transducer for common stationary workout," 2017 IEEE 4th International Conference on Smart Instrumentation, Measurement and Application (ICSIMA), Putrajaya, 2017, pp. 1-4. doi: 10.1109/ICSIMA.2017.8312007.

[18] D. Motter, J. V. Lavarda, F. A. Dias and S. S. da, "Vibration Energy Harvesting Using Piezoelectric Transducer and NonControlled Rectifiers Circuits," J. Braz. Soc. Mech. Sci. \& Eng., vol. 34, no. spe, pp. 378385, 2012. doi: 10.1590/S1678-58782012000500006

[19] A. Toprak y O. Tigli, "Piezoelectric energy harvesting: State-of-the-art and challenges," Appl. Phys. Rev., vol. 1, no. 3, pp. 031104, 2014. doi: $10.1063 / 1.4896166$

[20] Yiming Liu, Geng Tian, Yong Wang, Junhong Lin, Qiming Zhang, y H. F. Hofmann, "Active Piezoelectric Energy Harvesting: General Principle and Experimental Demonstration", J. Intell. Mater. Syst. Struct., vol. 20, no. 5, pp. 575-585, 2009. doi: 10.1177/1045389X08098195 